\title{
Reparating Women's Rights Violation Within Aceh Truth and Reconciliation Commission (TRC)
}

\author{
M. Ya'kub Aiyub Kadir ${ }^{*}$ \\ Faculty of Law, Syiah Kuala University, Aceh, Indonesia \\ Firmanila** \\ Faculty of Law, Syiah Kuala University, Aceh, Indonesia
}

Article Received: 29th October 2019; Accepted: 22 ${ }^{\text {nd }}$ January 2020; Published: $31^{\text {st }}$ January 2020

\begin{abstract}
The establishment of Aceh TRC is based on the 2005 peace agreement between the Indonesian Government and the Free Aceh Movement (GAM), which then regulated under Act No. 11 year 2006 on Governing of Aceh, and was manifested through the Aceh Qanun No. 17 year 2013 on Aceh TRC. Three years later, the commissioner of Aceh TRC was chosen and inaugurated by Aceh House of Representatives in July 2016. This paper investigates Aceh $T R C$ and its progress in fulfilling the rights of women as the victim of Aceh's conflict, challenges and some recommendations for better implementation of TRC. Using normative and empirical research, this paper found that Aceh TRC is an institution to uncover the truth of the past human rights violations, to achieve reconciliation and to recommend a comprehensive reparation. Currently (May 2019), Aceh TRC is collecting data to achieve the first goal that is uncovering the truth, while the rights of women as victims in Aceh's conflict is remain alienated. It is recommended that Aceh TRC should implement the urgent reparations as soon as possible considering the condition of the women's victim and their rights, and also for the central and provincial government to be supportive in terms of financial and moral support.
\end{abstract}

Keywords: Armed Conflict; Peace Agreement; Aceh Truth and Reconciliation Commission; Women's rights; Victim.

How to cite: Aiyub Kadir, M. Ya'kub, and Firmanila Firmanila. "Reparating Women's Rights Violation Within Aceh Truth and Reconciliation Commission (TRC) ." Udayana Journal of Law and Culture 4, no. 1 (2020): 21-38. https://doi.org/https://doi.org/10.24843/UJLC.2020.v04.i01.p02. 


\section{Introduction}

\subsection{Background}

Humans as zoon politicon have different views or opinions in daily life, ${ }^{1}$ which commonly contribute to a dispute or even more become a conflict. When such a conflict occurred, generally, there are two ways to resolve, through litigation or non-litigation process. Litigation process is the effort to solve the law dispute through the court, meanwhile non-litigation process is being implemented outside the court by doing negotiation, mediation, conciliation, arbitration. ${ }^{2}$ However, in some conditions, some conflicts cannot be solved through those ways, particularly concerning the historical injustice of a people in a state, and commonly known an armed conflict. Armed conflict is not only disturbing the national security but also the impact is very detrimental. Although armed conflict occurs between combatants, the impact of an armed conflict was not only felt by combatants but also by non-combatants.

Based on Article 4 paragraph 1 of Geneva Convention 1949, noncombatants defines as people who are not or no longer taking part in hostilities, including armed forces members who have laid down their arms, and those placed hors de combat by sickness, detention, wounded, shall in all circumstances be protected and treated under the humanity, without any adverse distinction on race, color, religion or faith, sex, birth or wealth, or any other similar criteria. ${ }^{3}$ In International Law, there is a principle known as distinction principle that applies on armed conflict. This principle regulates that the parties of the conflict must at all times distinguish between civilian objects and military objectives. ${ }^{4}$ Therefore, any military attacks must not be directed against civilians. The implementation of this principle can be seen in Article 48 of the Second Additional Protocol (1977) which states:

In order to ensure respect for and protection of the civilian population and civilian objects, the parties to the conflict shall at all times distinguish between the civilian population and combatants and between civilian objects and military objectives and accordingly shall direct their operations only against military objectives ${ }^{5}$

Those regulations aim to guarantee the protection of civilians. But in fact, there are still violations towards this principle. The grave violation of

1 Herbert Gintis, Carel Van Schaik, Christopher Boehm, "Zoon Politikon: The Evolutionary Origins of Human Political Systems," Current Anthropology 56, no. 3 (2015): 340-341 2012)

2 Tania Sourdin. Alternative Dispute Resolution, 4th ed (Pyrmont: Thomson Reuters,

3 Read Article 4 paragraph 1 of Convention (IV) relative to the Protection of Civilian Persons in Time of War. Geneva, 12 August 1949 (Geneva Convention 1949 on Protection to Civilians)

4 IHL Database of ICRC about Customary IHL Rule 7, https://ihldatabases.icrc.org>ihl

5 Read Article 48 of Protocol Additional to the Geneva Conventions of 12 August 1949, and relating to the Protection of Victims of Non-International Armed Conflicts (Protocol II), 8 June 1977 
human rights mostly comes from violations that occurred in hostilities, such as the violation that occurred in the Aceh conflict. 6

The conflict that was categorized as an armed conflict in Aceh occurred for almost thirty years between the Free Aceh Movement (GAM) and the Indonesian Armed Forces (TNI). ${ }^{7}$ At that time, both GAM and TNI did violations against civilians. The violations inter alia; kidnapping, torture, murder, and, rape. ${ }^{8}$ The crimes injured the victims, physically and mentally. Moreover, article 27 of The Geneva Convention 1949 describes the rights of civilians including the rights relating to them as a person, their honor, their family, their religious convictions and practices, and their manners and customs. All those rights should be protected in all circumstances. They shall, at all times, get all the treatment based on humanity, and free from any violent acts or threats like insults and public curiosity. ${ }^{9}$

This research focuses on women victims. Abuse towards women is one of the violations that commonly occurred in an armed conflict, whereas the woman should be protected and treated humanely under the Geneva Convention. Women shall especially be protected against any attack on their honor, in particular against rape, forced prostitution, or any form of indecent assault without prejudice to the provisions relating to their state of health, age and sex, all protected persons shall be treated with the same consideration by the parties of the conflict. Any adverse distinction based on a particular race, religion or political opinion should be excluded. The Parties to the conflict may take such measures of control and security in regard to protect the civilian, especially a woman which become so necessary as a result of the armed conflict. ${ }^{10}$

The Convention on the Elimination of All Forms of Discrimination Against Women (CEDAW) defines the discrimination against women as the action of any distinction, restriction or exclusion regarding human rights and fundamental freedom of the women in such field, such as in the economic, political, social, cultural, civil, etc. Those actions have the purpose to impair the exercise and enjoyment the human rights by women with the ground of sex, irrespective of their status with the basis of equality of men and women. ${ }^{11}$ The establishment of regulations on Human Rights is also part of compliance with International Law of Human Rights that have

${ }^{6}$ Wiratmadinata, An Evolving Model for Conflict Transformation And Peacebuilding in Aceh. Banda Aceh: Aceh Justice Resource Centre, 2009, 1.

${ }^{7}$ Ahmad Farhan Hamid. Jalan Damai Nanggroe Endatu (Jakarta: Penerbit Suara Bebas, 2006), 58 .

8 Yusuf Al-Qardhawy Al-Asyi. Sejarah dan Tujuan Pemberontakan GAM Menurut Hukum International (Banda Aceh: Yayasan PeNA, 2018), 9.

9 International Committee of The Red Cross, "Treaties, States Parties and Commentaries", https://ihl-databases.icrc.org

10 Read Article 24 Geneva Convention 1949 on Protection to Civilians. See more explanation in Lauren E. Schroeder, "The Rights of Muslim Women in the Middle East: A Pathfinder", International Journal of Legal Information, Vol 37 (1) 2009; Sally Engle Merry, "Constructing a Global Law-Violence against Women and the Human Rights System, Law \& Social Inquiry" 28, no. 4 (2003); and Marsha A. Freeman, "The Human Rights of Women under the CEDAW Convention: Complexities and Opportunities of Compliance, Proceedings of the ASIL Annual Meeting, Vol 91, 1997.

${ }^{11}$ Article 1 of Convention on the Elimination of All Forms of Discrimination Against Women (CEDAW) 1979, http://www.un.org/womenwatch/daw/cedaw/ 
been ratified by Indonesia since Act No. 5 of 1998 regarding the Legalization of Convention Against Torture and Other Cruel, Inhuman or Degrading Treatment or Punishment, and Law Number 29 of 1999 regarding the Convention Ratification on the Elimination of All Forms of Discrimination. ${ }^{12}$

Resolving human rights violation issues during Aceh conflict time was the responsibility of the government of Aceh which should be understood as the reason behind the establishment of the Truth and Reconciliation Commission (TRC). This commission is one of the government's efforts to settle and discover the truth from the conflict. The establishment of regulation on the Truth and Reconciliation Commission was an integral part of Constitutional Court Decision Number 6/PUU-IV/2006 which became urgent and fundamental needs. ${ }^{13}$ But there was an absence of law since the Act No. 27 year 2004 of Truth and Reconciliation had been annulled by the Constitutional Court. ${ }^{14}$ Some institutions which filed judicial review before Constitutional Court to revoke Article 1 paragraph 9 about amnesty, Article 27 about compensation and rehabilitation for the victim was depended on the amnesty for the perpetrator, and Article 44 of Act No. 27 year 2004 on Truth and Reconciliation Commission with the reason that those articles deemed to be against the 1945 Constitution. The court was in opinion that amnesty could not be implemented to the perpetrator of the brave violations of human rights. ${ }^{15}$ Then about compensation and rehabilitation for the victim was not dependent on the amnesty. TRC aims to disclose the truth of the conflict and provides the reparation and compensation as a form of state responsibility and perpetrators for violations committed to the victim. ${ }^{16}$

Aceh TRC was established under Aceh Qanun No.17 year 2013 through the Act No. 11 year 2006 about Aceh's Government as mandatory of an agreement between Indonesian Government and Free Aceh Movement (GAM) regarding their commitment to a peaceful, comprehensive and sustainable solution to the Aceh conflict (known as MoU Helsinki). ${ }^{17}$

Based on the data by Aceh TRC accessed on April 9th, 2019 there are 1300 statements collected in the field. The Statement Givers could be the victim, the family member of the victim, the witness, or the colleague of the victim. More than 20\% of those statements are about the violations experienced by women. ${ }^{18}$ The violations include torture, abduction, murder, sex abuse, detention, deprivation of property, etc. The data were submitted by six districts of Aceh's province, whilst there are a total of 23 districts in

${ }^{12}$ M. Ya'kub Aiyub Kadir, "The Urgency of Establishing the Truth and Reconciliation Commission in Aceh", Kanun: Jurnal Imu Hukum 17, No. 3 (2015).

${ }^{13}$ Ali Abdurrahman and Mei Susanto, "Urgensi Pembentukan Undang-Undang Komisi Kebenaran dan Rekonsiliasi di Indonesia dalam Upaya Penuntasan Pelanggaran HAM Berat di Masa Lalu." Padjadjaran Journal of Law 3, no. 3 (2016): 509-530.

${ }^{14}$ Purnomo Sucipto, "Penyelesaian Pelanggaran HAM Berat Masa Lalu Melalui KKR", https://setkab.go.id

15 Jiwon Suh, "Preemptive Transitional Justice Policies in Aceh, Indonesia." Southeast Asian Studies 4, no. 1 (2015): 95-124.

16 KKR Aceh, Mengenal KKR Aceh, Aceh TRC Handbook, 13.

17 Read the Operational Variables of this research 12 for more information about MoU Helsinki.

18 Based on data by Ainal Mardhiah as Commissioner of Aceh Truth and Reconsiliation Commission. April 9, 2019 
Aceh. It proved that the state had failed to protect women's victims during armed conflicts. Meanwhile, human rights should be respected in all legal circumstances. ${ }^{19}$

In this research, there are two women victims as the samples of the issues $(\mathrm{A}$, and $\mathrm{M})$. They were damaged during the Aceh conflict. A was a wife of the Free Aceh Movement (GAM) Governor and a mother of two children. Even though her husband was a combatant, she has never been involved in any of a GAM activity. In 2003, TNI members detained and tortured her in a remote mountain in Aceh, ${ }^{20}$ and the kind of tortured refers to beating using wood. TNI members had previously stolen the ship of A and damaged A's house. Even after the end of the conflict, the aftermath of the incident was still endured by A. Around the same time, $\mathrm{M}$ was also damaged, detained and tortured. $\mathrm{M}$ was having a baby when she was detained, which prevented her from breastfeeding her baby for a day. Meanwhile, there were other four children who needed to be taken care of. When the interview was being conducted, M confirmed that her legs still pains to this day since the torturing day. But she's never been through any kind of recovery attempts such as be given remedies, restitution, or rehabilitation. ${ }^{21}$ Stories above show that during the conflict time, women are often bound to take the role as the head of the family in order to replace the missing or dying husband to take in charge for livelihood and other duties such as taking care of the children, ensuring their education, food, and basic services, to income management. ${ }^{22}$

The end of conflicts does not mean the end of woman victims. Women mostly continue to sacrifice and suffered in terms of medication, physic, psychology and socio-economic consequences of the torture long after it ended. That is why ensuring women's access to justice is important and requiring women to enjoy their rights such as rights to remedy, restitution, and rehabilitation. In this context, the role of Aceh TRC should be examined.

\subsection{Research Problem}

This paper inquires three research questions. Firstly, what is the meaning of TRC in the post-Aceh conflict context?. Secondly, to what extent has the Aceh TRC fulfilled woman rights as a victim in the Aceh conflict? Finally, what are the challenges facing TRC in the fulfilment of woman rights as a victim in the Aceh conflict?

19 Inter-Parliamentary Union, Human Rights, United Nations Human Rights Office of The High Commissioner, 2016, 22.

${ }^{20}$ Mountain in Aceh and the post of Indonesian Armed Forces (TNI).

21 Interviews conducted with the victim, (A) on June 16, 2019.

22 Debbi Schaubman, "Sociology, Social Lives, and Social Issue," in Women's Studies: A Recommended Bibliography, $3^{\text {th }}$ edition, ed. Linda A. Krikos and Cindy Ingold (London: Libraries Unlimited, 2004), 349. 


\subsection{Method/ResearchOutline}

This article utilised normative and empirical methods. Normative serves to see the law while empirical research is to explore how the law is implemented. For the first problem identification of this article, data obtained through the regulations and interview.

The methods used to obtain the primary data are interviews with respondents and informants, wherewith to obtain secondary and tertiary data was conducted a library research. In order to compile data in the research, primary and secondary data are applied. The Primary data is data obtained directly from the field related to the problems studied by conducting interviews with two victims (A and M), the Head of Aceh TRC, The Commissioner of Aceh TRC on women's department, a staff of Flower Aceh Institution, and the activist of women's rights.

Secondary data includes the following legal instruments; Geneva Convention (1949), Universal Declaration on Human Rights (1948), Convention on the Elimination of All Forms of Discrimination against Women 1979, Act No. 39/ 1999 on Human Rights, Act No. 27/ 2004 on TRC, MoU Helsinki 2005, Act No. 11/ 2006 on Aceh's Government, Aceh Qanun No. 17/ 2013 on Aceh TRC.

\subsection{Literature Review}

Aceh TRC is a non-judicial institution to solve the human rights violations that occurred during Aceh's conflict. ${ }^{23}$ The Aceh TRC is expected to operate from 2016 to 2021 and could be continued for the next period. ${ }^{24}$ The establishment of TRC's Aceh has three goals, they are: strengthening peace by revealing the truths about past of human rights violations; achieving reconciliation between the perpetrators of human rights violations, both individuals and institutions with the victims; and recommending comprehensive reparation for victims of human rights violations, in accordance with universal standards relating to the rights of victims. ${ }^{25}$

Aceh TRC aims to uncover the truth about the human rights violations that occurred whether in Aceh or abroad as long as it was related to Aceh's conflict. The first step is meant for the violations that have been done from December 4th 1976 until August 15th 2005 . The second step is meant for the violations that had been done before December $4^{\text {th }}, 1976$.

The second step can be done when the first step has been completed by TRC. It is shown that there is a retroactive principle in Aceh TRC's working and it could continue to the violence in the colonial era. ${ }^{26}$ Colonialera is an era when the practice of domination or practice of acquiring full or partial political control over another country, occupying it with settlers and

${ }^{23}$ M. Yakub Aiyub Kadir, in seminars on the relationship of Islamic law and international humanitarian law that has been held in Law Faculty, Syiah Kuala University on May 14, 2019.

${ }^{24}$ Read Article 14 paragraph 2 of Aceh Qanun on TRC No. 17 year 2013.

${ }^{25}$ Bisma Yadhi Putra, "Aceh Truth and Reconciliation Commission : A Diplomatic Brief", published on April 2, 2019, http://kkr-aceh.com/berita/aceh-truth-andreconciliation-commission-a-diplomatic-brief

${ }^{26}$ Interviews conducted with the Head of TRC's Aceh, Afridal Darmi on May 8, 2019. 
exploiting it economically such as occurred in the Indonesian context. ${ }^{27}$ But rationally, it will be hard to uncover the truths from the very long times ago because the population keeps changing and the proofs that will be very difficult to unravel.

Uncovering the truth is aimed to: encourage policy changes and improvements to institutions that had resulted in past violations; to achieve accurate information about human rights violations and suspected grave human rights violations, based on the evidence and facts that have been collected, including analyzing the causes, underlying events, political and/or economic motivations, actions and actors both state and non-state institutions and their impact; to fulfil the rights of victims to obtain truth and justice; and to clarify the history of Aceh. ${ }^{28}$

To achieve the goals, Aceh TRC is working based on the principles of participation, transparency, prioritizing protection and recovery of victims, refuse amnesty, right of reply for the perpetrator, balanced proof, individual and institutional, responsibility, preventive action, complementary, diversity approach, gender perspective, professional. ${ }^{29}$

The head of Aceh TRC, Afridal Darmi stated that participation in these terms refers to volunteerism whether from victims or perpetrators regarding the uncovering of the truth. TRC does not have the right to force the victim to tell their painful experience and also cannot force the perpetrator to admit the crimes that they have committed. ${ }^{30}$

It was different from the South African TRC, where they have the power to call by force the perpetrators but has never been used. Because they realized that it would be impossible for them to force the generals to attend. But there was another way, namely by asking the court to present the person and charge them with hiding information. In the step of uncovering the truth, Aceh TRC cooperates with The Witness and Victim Protection Agency of Aceh. This collaboration is carried out by utilizing experts in matters of witness and victim protection. ${ }^{31}$

Based on the assumption that the perpetrator cannot be asked for justice because of his influence, the next problem is 'what is left for the victim'? That is why the step meant to uncover the truth is important, the victims want their voices to be heard. Then the next step is reconciliation. Reconciliation is the step to achieve peace between the victim and the perpetrator. The reconciliation forum was formed to bring together the perpetrator to ask the victim to apologize to them and the victim to forgive the perpetrator. ${ }^{32}$

Reconciliation mechanism as set out in Law No. 27 Year 2004 has a juridical consequence on the compensation to be provided to the victims such as compensation, restitution, and rehabilitation, as stated in this law

${ }^{27}$ See the historical self-determination conflict in Indonesia in M. Yakub Aiyub Kadir (2015), loc.cit. Also in Stanford Encyclopedia of Philosophy, "Colonialism", https://plato.stanford.edu/entries/colonialism/

${ }^{28}$ Read Aceh Qanun on TRC No.17 year 2013, Article 20.

${ }^{29} \mathrm{Ibid}$, Article 4.

${ }^{30}$ Based on participation principle, while the principle meant that based on the voluntary by the parties.

31 KKR Aceh, op.cit., 72-73.

32 Read Aceh Qanun No. 17 year 2013 about Aceh TRC, Article 1 paragraph 20. 
that the uncovering of truth is also for the interest of victims and/or their families who are beneficiaries for compensation, restitution, and/or rehabilitation. ${ }^{33}$ That is why the statement giver not only the victim, but it could be the family or the relatives of the victims.

Based on Aceh Qanun No. 17 year 2013, reconciliation is the result of a sequence of processes from uncovering the truth, recognition, and forgiveness, and the re-acceptance of victims and perpetrators by the community, through the Aceh TRC by using Aceh's customary mechanism in order to resolve human rights violations to create national peace and unity. The important point of the reconciliation is the desire of the perpetrator to escape from guilt and the desire to forgive by the victim. Aceh TRC has conducted some parties who want to be reconciled by Aceh TRC but until Mei 8, 2019, the time conducted an interview with the Head of Aceh TRC stated that they have not established the reconciliation forum yet.

Based on Aceh Qanun No. 17 year 2013, reconciliation is the result of a sequence of processes from uncovering the truth, recognition, and forgiveness, and the re-acceptance of victims and perpetrators by the community, through the Aceh TRC by using Aceh's customary mechanism in order to resolve human rights violations to create national peace and unity. The important point of the reconciliation is the desire of the perpetrator to escape from guilt and the desire to forgive by the victim. Aceh TRC has conducted some parties who want to be reconciled by Aceh TRC but until Mei 8, 2019, the time conducted an interview with the Head of Aceh TRC stated that they have not established the reconciliation forum yet. There are two hundred victims recorded to the urgent reparation but it could not be fulfilled because TRC was still waiting for the funding from Aceh's government. ${ }^{34}$

The Geneva Convention I for the Amelioration of the Condition of the Wounded and Sick in Armed Forces in the Field creates the provisions of equal treatment of both women and men. However, it has been indicated that women should be treated with all consideration due to their sex. ${ }^{35}$ Similarly, the Geneva Convention -III for the Treatment of Prisoners of War provides equality of treatment of women and men and ensures the treatment of women with all the regard due to their sex. Correspondingly Geneva Convention IV 1949 for the Protection of Civilian Persons in Time of War reads that women shall be especially protected against any attack on their honor, in particular against rape, enforced prostitution, or any form of indecent assault. ${ }^{36}$

In the long armed conflict situation, women are among the persons protected by the Fourth Geneva Convention in relation to the protection of civilian persons in the time of war. As mentioned in Article 3 of the common articles of the Geneva Convention (1949) that Women are protected by the foundational guarantees covering the treatment of persons not taking part

\footnotetext{
${ }^{33}$ Deddy Ardiyan Prasetyo, "Indonesia's Truth and Reconciliation Commission as a Mechanism for Dealing with Gross Violations of Human Rights", (Dissertation. Master of Law in Human Rights, The University of Hongkong, 2006), 11.

${ }^{34}$ Ibid.

35 Read Article 12 Geneva Convention 1949 on Protection to Civilians

36 Read Article 27 paragraph 2 of Geneva Convention 1949 on Protection to Civilians.
} 
in the war or hostilities. However, this article does not provide special protection for women. To guarantee access to justice for women to enjoy the principle equality before the law, ensuring that procedures are in line to guarantee non-discriminatory process to justice in general meaning, and also that women victim can accessible to remedies and the likes when their rights have been degraded. These rights are including Article 23 on the right to a remedy and Article 26 on the rights of equality before the law of the International Covenant on Civil and Political Rights (ICCPR) 1966. 37 In armed conflict, violence against women takes several forms. During the past decade, there are much attention that has been paid to by the global community about the link between gender-based violence and conflicts. The impact of the conflict damages women's lives, whether on civil and political or on economic and social terms.

Although currently many attempts to attack violations against women both during conflict or post-conflict circumstances, still women remain continued to be an object of violations. Several examples are sexual abuse, sexual slavery, rape, abduction, and other kinds of sexual abuses such as forced in nudity, and other public humiliation and violating acts. ${ }^{38}$ The current example is concerning the Rohingya case which has been attracted to international attention. ${ }^{39}$

The UN legal framework is concerned that Convention on the Elimination of all Forms of Discrimination against Women (CEDAW) 1979, then so-called the international instrument of women's rights, neither has any direct reference to the violence against women nor to the women's rights during the wartime. Nevertheless, it also has no provisions suspending its applicability during wars or armed conflicts. Therefore it has been indicated that state parties to Convention are obliged to follow and obey the Convention during armed conflict, state of emergency, within its jurisdiction, both in its own territory and in occupied territories if any. 40

Under general recommendation Number 19/1992, the Committee on the Elimination of Discrimination against Women (EDAW), confirmed that war or armed conflicts and the occupation of territories tend to lead to various issues such as prostitution, women trafficking and sexual assault of women, which necessitate specific tool to protect and punitive measures. ${ }^{41}$ Even more, this crime has been used by warring parties to be part of a tactic to win the battle. ${ }^{42}$

${ }^{37}$ Read Article 23 and 26 of International Covenant on Civil and Political Rights (ICCPR) 1996.

38 Rashida Manjoo and Calleigh McRaith, Manjoo, Rashida, and Calleigh McRaith. "Gender-based Violence and Justice in Conflict and Post-Conflict Areas." Cornell Int'l LJ 44 (2011): 11-31.

39 Elisabeth Rehn and Sirleaf Ellen Johnson. Women, War and Peace: The Independent Experts' Assessment on the Impact of Armed Conflict on Women and Women's Role in Peace-building. (New York: United Nations Development Fund for Women/UNIFEM, 2002). Michail Vagias, "The Prosecutor's Request Concerning the Rohingya Deportation to Bangladesh: Certain Procedural Questions", Leiden Journal of International Law 31, no.4 (2018).

40 Ibid.

${ }^{41}$ Rashida Manjoo and Calleigh McRaith, op.cit.

42 Elisabeth Rehn and Sirleaf Ellen, loc.cit. 
The Committee on the EDAW stated in its general recommendation Number 28 of 2010, that 'states parties must further ensure that women have recourse to affordable, accessible and timely remedies, with legal aid and assistance as necessary, to be settled in a fair hearing by a competent and independent court or tribunal, where appropriate'. Furthermore, the Basic Principles and Guidelines on the Right to a Remedy and Reparation for Victims of Grave Violations of International Human Rights Law and Serious Violations of International Humanitarian Law have called for state parties for providing proper assistance to victims, particularly women victim seeking access to justice system including legal aid and also ensuring adequate, effective and prompt remedies for victims of serious or grave violations (General Assembly Resolution 60/147). ${ }^{43}$

Additionally, the CEDAW Committee has defined violence against women as a form of discrimination against women and one of the grave breaches of women's rights. Thus the Committee has mentioned the situation of women in the armed conflicts, and the issues of violence against women in particular, in its Reports submitted on an exceptional basis and in its General recommendation Number 30 on women in conflict prevention, conflict, and post-conflict circumstances. ${ }^{44}$

The effective remedy is relevant for the realization of all packs of human rights and is to be enjoyed on the basis of equality, without discrimination of any form such as on the basis of sex or gender. The Human Rights Committee, under its (General Comment No. 31 year 2004), stated that for the right to an effective remedy to be fulfilled, reparation has to be provided to the victim of a human rights violation. Moreover, CEDAW requires State parties to establish legal protection of the rights of women on an equal basis with men, to ensure through competent national tribunals and other public institutions the effective protection of women against any act of discrimination. ${ }^{45}$

When any conflict has ended does not reflect into an end of the violence against women. ${ }^{46}$ Women with severe mental illness need special attention because of serious wound or trauma which must be felt by any victim could be disturbing to their future life. That is why public awareness needs to be created with respect to the following:

1. Women need more care and protection.

2. The negative attitude toward mental illness.

3. The society has to accept people with mental illness.

4. Good family support greatly improves the prognosis.

5. The mental illness on the victim should be promptly treated. ${ }^{47}$

${ }^{43}$ The International Commission of Jurists, The Right to a Remedy and Reparation for Grave Human Rights Violations, Practitioners Guide No. 2 Revised Edition, 2018.

${ }^{44}$ Natalia Buchowska, "Violated or protected. Women's rights in armed conflicts after the Second World War." International Comparative Jurisprudence 2, no. 2 (2016): 72-80.

45 Read Article 2(c) of CEDAW, UN Women, "Convention on the Elimination of All Forms of Discrimination against Women", CEDAW 29th Session 30, https://www.un.org

46 United Nations, "Women's human rights and gender-related concerns in situations of conflict and instability", United Nations Human Rights Office of The HighCommissioner, https://www.ohchr.org/EN/Issues/Women/WRGS/Pages/PeaceAndSecurity.aspx

47 Sharma Indira, "Violence against Women: Where Are the Solutions?." Indian Journal of Psychiatry 57, no. 2 (2015): 131. 
In addition, There is the due diligence of states to prosecute, ${ }^{48}$ punish and compensate for human rights violations committed by non-state actors has also become a well-recognized international norm. States have to ensure that all victims particularly women of human rights violations have accessed to immediate tools of reparation, that perpetrators of crime are prosecuted and punished, and that mechanisms for this are accessible to women. ${ }^{49} \mathrm{It}$ can be access to criminal or civil remedies so that the establishment of effective protection, support, and rehabilitation services for survivors of violence occurred. In Indonesia, the definition of human rights violations or abuses is currently limited to those rights under Law No.39/ 1999 on Human Rights. 50

MoU Helsinki 2005 mandated a judicial mechanism, in the form of a human rights court, and a non-judicial mechanism, in the form of a TRC, to address human rights violations that occurred during Aceh's conflict period. These mechanisms have been stipulated also in the Aceh Government's Law No. 11/ 2006. The Aceh TRC and the human rights court are both obligations of both the Government of Aceh and the Government of Indonesia to address human rights violations and to fulfil victims' rights to truth, justice, and reparation. ${ }^{51}$

In the context of human rights violation, the word of remedy could be meant as efforts or actions of the state responsibility form to provide maximum and effective efforts especially to the victims of human rights violation, of which the form is like the reparation. The Universal Declaration of Human Rights (UDHR) stated that "Everyone has the right to an effective remedy by the competent national tribunals for acts violating the fundamental rights granted him by the constitution or by law." 52

Beside stated in the UDHR, there are some international instruments that also stipulate the issue of remedy, among others, the International Convention on Civil and Political Rights (ICCPR) 53 and the Convention against Torture (CAT). ${ }^{54}$ This instrument comprises an obligation to ensure and respect for implementing international human rights law.

48 Based on Max Planck Encyclopedia of Public International Law (MPEPIL), definition of due diligence is an obligation of conduct on the part of a subject of law, Oxford Public International Law, 2010.

49 United Nations, "Basic Principles and Guidelines on the Right to a Remedy and Reparation for Victims of Grave Violations of International Human Rights Law and Serious Violations of International Humanitarian Law”, 2005 https://www.ohchr.org/EN/ProfessionalInterest/Pages/RemedyAndReparation.aspx

50 Deddy Ardiyan Prasetyo, op.cit., 9.

${ }^{51}$ Asia Justice and Rights, "Press Release: First-Year Anniversary of the Aceh Truth and Reconciliation Commission", 2017. https://asia-ajar.org/2017/11/press-release-firstyear-anniversary-aceh-trc/

52 Read Article 8 of Universal Declaration of Human Rights 1948.

53 Commentary to the Declaration on the Rights and Responsibility of Individuals, Groups and Organs of Society to Promote and Protect Universally Recognized Human Rights and Fundamental Freedoms, "The Rights to an effective remedy", Chapter VIII, Juli 2011.

54 Ibid. 


\section{Result and Discussion}

\subsection{The Role of Aceh TRC regarding Women's Rights as Victim of Aceh's Conflict}

There is known a distinction principle in International Humanitarian Law that must be respected by the combatant in hostilities. The principle means that the combatant should distinguish the civilians and combatants as well as distinguish civil objects and military objectives. In Aceh's conflict, the combatant has violated this principle. Many protected persons got damages by the combatant, whether for their objects or themself. Most damages were felt by women because at that time the men only have two choices, went to the mountain or moved to outside Aceh. ${ }^{55}$ That is why the women who often faced the combatant. There are many violations felt by women, such as: torture, murder, destruction, detention, physical attack, enforced disappearance, threat, arrest, sexual violence, extortion, robbery, theft, and etc. ${ }^{56}$

Armed Conflict damaged the women and place them to a heightened risk of sexual, physical and psychological threat. Studies show that the roots of such violence which occurred both in peace and in conflict are similar, which is unequal power relations (gender bias) between men and women and a patriarchal value system in the community. ${ }^{57}$

The violence against women occurred in many countries and this is a big issue. The reason why the women as victim in any acts of violence would be a big issue and problem in the world is that women have a certain status in a certain area. For example, women have the highest status in Aceh's society. It can be shown with the view of Aceh's citizens that they may be persecuted but not with the women in their family. The other reason is based on cultural stereotypes and customs spread all over the world, women are seen as unequal to men. Such a perception of women's position in society is the major factor influencing the prevalent problem of violence against women. Due to the unequal cultural position of women even in peace situations, women become particularly vulnerable to violence and in reality become victims of violence more often than men. ${ }^{58}$ As stated in the report of the UN Declaration on the Elimination of Violence Against Women, that violence against women was an impact of unequal power relations between men and women in a fragile community, resulting in suppression or discrimination against women. The developments in this period show that the violence is real so that we need an act for the prevention of such crimes as soon as possible. To solve such human rights violations, many countries in the world have made many efforts. ${ }^{59}$ Aceh TRC is an effort of the Aceh's Government in this aspect.

55 Interviews conducted with Nursiti on May 13, 2019. She was a women's activist of Aceh.

56 Data from Ainal Mardhiah.

57 Reilly Niamh, Women's Human Rights. (Polity Press, 2009), 98.

58 Buchowska Natalia, op.cit., 2.

59 See several examples, e.g. Judith Gardam, "Women, Human Rights and International Humanitarian Law", International Review of the Red Cross Archive 38, no.324 (1998); Hanafi Arief, "Legal Protection Against Women Victims by The Indonesian Domestik Violence Act No. 23 year 2004", Sriwijaya Law Review 1, no.1 (2017); L. Muthoni Wanyeki 
Nowadays, Aceh TRC does the first goals of TRC that uncover the truth. The way they use to fulfil this goal is collecting statements, especially from victims. Until 9 April 2019, the amount of data that collected was 1300 statements, 266 of them are stated by women. Those 266 statements were stated by 36 women victims, 39 statements by women who have a relation with the victims, 45 statements by the women witnesses, and 146 statements by women's relatives of victims. All data collected from 12 districts of Aceh. In each district have one regional coordinator and three servant officers to collect the data. ${ }^{60}$ Based on data, the violence faced by women included torture, destruction, detention, physical attack, enforced disappearance, murder, threats to victims, threats to the victim's family, sexual violence, thievery, and etc.

The data also show that the amount of women's victims was 57 people. Where the number of statements was 1300 and women's statement giver was 266 people. It means that the amount of the victim does not mean the same as the amount of statement. The rest of the statement giver, 1034 men as statement giver. It could be from men as a victim, men who have a relation with the victim, men witnesses, or men's relatives of the victim. ${ }^{61}$

After uncovering the truth, the next step to get the reparation is reconciliation. It means that the victims need to pass some steps and will take many times to get the reparation. Even though, women victims should be handled with certain treatment with the consideration there will take different evidence to prove their statement. ${ }^{62}$ The certain treatment refers to the action take by Aceh TRC in fulfilling the rights of women's victims, such as the rights of rehabilitation is urgently required. It could be through providing an immediate treatment that depends on the wound suffered by the victim, for example, physical control and psychological therapy. ${ }^{63}$

The reparation toward victims of human rights violation according to Dinah Shelton could be restitution, compensation, satisfaction, and guarantees non-repetition. ${ }^{64}$ Meanwhile, the Black's Law mentions the remedies are the field of law dealing with the means of enforcing rights and redressing a wrong. ${ }^{65}$ Besides that, the remedy also gives guarantees a procedural and a substantive claim. ${ }^{66}$ The right to a remedy when rights are violated is guaranteed by international human rights instruments. The victim's rights refer to a set of norms that determine the treatment and

(ed.), Women and Land in Africa-Culture, Religion and Realizing Women's Rights (Zed Books, 2003).

60 Data from Ainal Mardhiah.

61 Ibid.

62 Interviews conducted with an Aceh Women's Activist, Nursiti on May 13, 2019.

63 Ani Purwanti, "Protection and Rehabilitation for Women Victims of Violence According to Indonesian Law (Study on Central Java Government's Handling Through KPK2BGA)," Diponegoro Law Review 2, no.2 (2017); 312-325.

64 Hao Duy Phan, "Reparations to Victims of Gross Human Rights Violations: The Case of Cambodia." E. Asia L. Rev. 4 (2009): 277.

65 Cristie Ford, "Dogs and Tails: Remedies in Administrative Law" in Administrative Law in Context, ed. Lorne Sossin and Colleen Flood (Toronto: Emond Montgomery, 2013).

66 Theo Van Boven, "Victim-Oriented Perspectives: Rights and Realities," in Victims of International Crimes: An Interdisciplinary Discourse, ed. Thorsten Bonacker and Christoph Safferling (The Hague: T.M.C. Asser Press, 2013), 17-27. 
entitlements that victims of human rights violations have with regard to remedies and reparations. ${ }^{67}$

So far, Aceh TRC does its duty on equality before the law. Equality before the law shown through the principle of Aceh work's principle, that is participation and transparency. Both victims and perpetrators can tell the truth to Aceh TRC whenever they want. ${ }^{68}$ On the other hand, Aceh TRC has not fulfilled yet the women's rights to remedy, restitution, and rehabilitation. It can be seen from the data that Aceh TRC did not give the remedy or any kind of reparations to women's victim. And also proven from the sample of women's victims in this research that they did not get the right to remedy, restitution and rehabilitation from Aceh TRC.

\subsection{The Challenges Facing Aceh TRC}

It is common sense that in retributive justice sense, the justification for amnesty was often unacceptable to many victims. ${ }^{69}$ Politicians or peacemakers may have been able to justify the exchange of formal justice for what they called peace, but it has been difficult for victims to consider while the perpetrators have received amnesty. But in Aceh TRC, there is no amnesty for the perpetrator of the grave human rights violations. Justice is an essential element and sometimes prudent component of a victim's recovery and psychological healing. ${ }^{70}$

All people around the world have shared their desires to get away from any armed conflicts which have evidently contributed to brutal women victims of force. ${ }^{71}$ Aceh TRC existed because that was authorized by Aceh's government. The funding of Aceh TRC came from the regional income and expenditure budget. The limited budget impact on the performance of TRC. With a limited budget, the staff-owned is limited so the work is not optimal. Not optimal here is because they work slowly. Meanwhile, the reconciliation aspect should be done as soon as possible. TRC collecting statements by themselves so it will take many times.

Another challenge is proven from the urgent reparation process. From the definition can be known that the urgent reparation is the step that TRC should fulfil without passed the uncover truth and reconciliation. This has not fulfilled by TRC while they have the data about the victim who needs urgent reparation. Based on Afridal Darmi statement there are two hundred victims recorded to the urgent reparation but it has not fulfilled because TRC still waiting for the funding from Aceh's government. But he was not sure until when to wait. 72

67 Jemima Garcia-Godos, "Victims' Rights and Distributive Justice: In Search of Actors", Human Rights Review 14, no.3 (2013): 241-255.

68 Interviews conducted with the Head of TRC's Aceh, AfridalDarmi on May 8, 2019.

69 Ibid.

70 Kaminer Debra, (et al), The Truth and Reconciliation Commission in South Africa: Relation to Psychiatric Status and Forgiveness Among Survivors of Human Rights Abuse, 178 Brit.J.OFPsychiatrv 373, 377, 2001.

${ }^{71}$ See Hans-Peter Kaul, "Victims' Rights and Peace," in Victims of International Crimes: An Interdisciplinary Discourse, ed. Thorsten Bonacker and Christoph Safferling (The Hague: T.M.C. Asser Press, 2013), 227.

72 Interviews conducted with the Head of TRC's Aceh, Afridal Darmi on May 8, 2019. 


\section{Conclusion}

There are three goals of establishing the Aceh TRC are strengthening peace by uncovering the truth about the past human rights violations, achieving reconciliation between the perpetrators of human rights violations, and recommending comprehensive reparation for victims of human rights violations. They should fulfil the first step so they can continue for the next one. Currently (2019), TRC is still collecting data to achieve the first goal of uncovering the truth.

Thus far, Aceh TRC has not fulfilled yet the women's rights to remedy, restitution, and rehabilitation. It can be seen from the data that Aceh TRC has not given the remedy or any kind of reparations to women's victim. There are some circumstances facing of Aceh TRC in achieving their goals. The main point of the challenge is the lack of attention from the central and provincial governments to help the performance of TRC's Aceh. Particularly, the lack of funding that adversely impacts the whole performance of Aceh TRC. Even more, the need for reparation for victims remains questionable, as no funding provided.

Even though they have to carry out three steps sequentially; uncovering the truth, reconciliation, and reparation, the Aceh TRC should implement the urgent reparations as soon as possible considering the condition of the victims who need urgent reparation and cannot get their rights if handled with sequential stages. Aceh TRC has to give special attention to women's victim such as creates the implementing policies on women's victims and fulfil their rights as soon as possible. Because in many cases, the evidence would be hard to find so Aceh TRC has to work faster. Finally, the central government should be supportive of Aceh's TRC as well as Aceh provincial government. In particular, providing sufficient funding so Aceh TRC can fulfil the rights of women's victim as soon as possible.

\section{BIBLIOGRAPHY}

\section{Book}

Al-Asyi, Yusuf Al-Qardhawy. Sejarah dan Tujuan Pemberontakan GAM Menurut Hukum International. Banda Aceh :Yayasan PeNA, 2018.

Hamid, A.F. Jalan Damai Nanggroe Endatu. Jakarta :Penerbit Suara Bebas, 2006.

Rehn, Elisabeth and Ellen Johnson Sirleaf. Women, War and Peace: The Independent Experts' Assessment on the Impact of Armed Conflict on Women and Women's Role in Peace-building. New York: United Nations Development Fund for Women (UNIFEM), 2002.

Reilly, Niamh. Women's Human Rights, Polity Press : 2009.

Tania, Sourdin. Alternative Dispute Resolution, 4th ed, Pyrmont: Thomson Reuters, 2012.

Wanyeki, L. Muthoni (ed.), Women and Land in Africa: Culture, Religion and Realizing Women's Rights. Zed Books, 2003. 


\section{Chapter in an Edited Book}

Ford, Cristie. "Dogs and Tails: Remedies in Administrative Law" in Administrative Law in Context, edited by Lorne Sossin and Colleen Flood, 85-123. Toronto: Emond Montgomery, 2013.

Kaul, Hans-Peter, "Victims' Rights and Peace," In Victims of International Crimes: An Interdisciplinary Discourse, edited by Thorsten Bonacker and Christoph Safferling, 223-231. The Hague: Asser Press, 2013.

Schaubman, Debby. "Sociology, Social Lives, and Social Issue", in Women's Studies: A Recommended Bibliography" $3^{\text {th }}$ edition, edited by Linda A. Krikos and Cindy Ingold. 304-358. London: Libraries Unlimited, 2004.

Van Boven, Theo. "Victim-Oriented Perspectives: Rights and Realities." In Victims of International Crimes: An Interdisciplinary Discourse, edited by Thorsten Bonacker and Christoph Safferling, 17-27. The Hague: Asser Press, 2013.

\section{Journal Article}

Abdurrahman, Ali, and Mei Susanto. "Urgensi Pembentukan UndangUndang Komisi Kebenaran dan Rekonsiliasi di Indonesia dalam Upaya Penuntasan Pelanggaran HAM Berat di Masa Lalu." Padjadjaran Journal of Law 3, no. 3 (2016): 509-530. https: / / doi.org/10.22304/pjih.v3.n3.a4

Arief, Hanafi. "Legal Protection Against Women Victims by The Indonesian Domestic Violence Act 23, 2004." Sriwijaya Law Review 1, no. 1 (2017): 110-121. http:/ / dx.doi.org/10.28946/slrev.Vol1.Iss 1.12.pp110-121

Buchowska, Natalia. "Violated or Protected. Women's Rights in Armed Conflicts after the Second World War." International Comparative Jurisprudence 2, no. 2 (2016): 72-80.

Freeman, Marsha A. "The Human Rights of Women under the CEDAW Convention: Complexities and opportunities of Compliance." In Proceedings of the ASIL Annual Meeting, vol. 91, pp. 378-383. Cambridge University $\quad 1997$. https://doi.org/10.1017/S0272503700066143

Garcia-Godos, Jemima. "Victims' Rights and Distributive Justice: In Search of Actors." Human Rights Review 14, no. 3 (2013): 241-255. https://doi.org/10.1007/s12142-013-0272-4

Gardam, Judith. "Women, Human Rights and International Humanitarian Law." International Review of the Red Cross Archive 38, no. 324 (1998): 421-432. https://doi.org/10.1017/S0020860400091221

Gintis, Herbert, Carel Van Schaik, Christopher Boehm. "Zoon politikon: The Evolutionary Origins of Human Political Systems." Current Anthropology 56, no. 3 (2015): 327-353.

Kadir, M. Ya'kub Aiyub, "Revisiting Self-determination Conflicts in Indonesia: an International Law Perspective." Indonesia Law Review 5, no. 2: 123-139. http://dx.doi.org/10.15742/ilrev.v5n2.116

Kadir, M. Ya'kub Aiyub. "The Urgency of Establishing the Truth and Reconciliation Commission in Aceh: Against National Amnesia." Kanun: Jurnal Ilmu Hukum 17, no. 3 (2015): 495-509.

Manjoo, Rashida, and Calleigh McRaith. "Gender-based Violence and 
Justice in Conflict and Post-Conflict Areas." Cornell Int'l LJ 44 (2011): 11-31.

Merry, Sally Engle. "Constructing a Global Law-violence against Women and the Human Rights System." Law \& Social Inquiry 28, no. 4 (2003): 941-977. https://doi.org/10.1111/j.1747-4469.2003.tb00828.x

Phan, Hao Duy. "Reparations to Victims of Gross Human Rights Violations: The Case of Cambodia." E. Asia L. Rev. 4 (2009): 277-298.

Purwanti, Ani, "Protection and Rehabilitation for Women Victims of Violence According to Indonesian Law (Study on Central Java Government's Handling Through KPK2BGA)," Diponegoro Law Review 2, no.2 (2017); 312-325. https://doi.org/10.14710/dilrev.2.2.2017.68-81

Schroeder, Lauren E. "The Rights of Muslim Women in the Middle East: A Pathfinder." International Journal of Legal Information 37, no. 1 (2009): 135-165. https://doi.org/10.1017/S0731126500003474

Sharma, Indira. "Violence against Women: Where Are the Solutions?." Indian Journal of Psychiatry 57, no. 2 (2015): 131. https://doi.org/10.4103/0019-5545.158133

Suh, Jiwon. "Preemptive transitional justice policies in Aceh, Indonesia." Southeast Asian Studies 4, no. 1 (2015): 95-124. https://doi.org/10.20495/seas.4.1_95

Vagias, Michail. "The Prosecutor's Request Concerning the Rohingya Deportation to Bangladesh: Certain Procedural Questions." Leiden Journal of International Law 31, no. 4 (2018): 981-1002. https://doi.org/10.1017/S0922156518000481

\section{Thesis or Dissertation}

Prasetyo, Deddy Ardian. "Indonesia's Truth and Reconciliation Commission as a Mechanism for Dealing with Gross Violations of Human Rights", Dissertation. Master of Law in Human Rights, The University of Hongkong, 2006.

\section{Legal Documents}

Aceh Qanun No.17 year 2013 on Aceh Truth and Reconciliation Commission Act of the Republic of Indonesia No. 11 year 2006 on Aceh's Government Act of the Republic of Indonesia No. 39 year 1999 on Human Rights

Protocol Additional to the Geneva Conventions of 12 August 1949, and relating to the Protection of Victims of Non-International Armed Conflicts (Protocol II), 8 June 1977

Convention on the Elimination of All Forms of Discrimination Against Woman (1979)

Convention (IV) relative to the Protection of Civilian Persons in Time of War. Geneva, 12 August 1949.

Memorandum of Understanding (MoU) Helsinki, 15 August 2005

International Covenant on Civil and Political Rights (1996).

Universal Declaration of Human Rights (1948) 


\section{Other Documents}

The International Commission of Jurists, The Right to a Remedy and Reparation for Gross Human Rights Violations, Practitioners Guide No. 2 Revised Edition, 2018.

\section{Interview}

Women's victims: initial A and M

Head of Aceh Truth and Reconciliation Commission

Commissioner of Aceh Truth and Reconciliation Commission on Women's Department

Staff of Flower Aceh Institution

Activist of Women's Rights

\section{Website Content}

Asia Justice and Rights, "Press Release: First-Year Anniversary of the Aceh Truth and Reconciliation Commission", Last Modified November 1, 2017. $\quad$ https://asia-ajar.org/2017/11/press-release-first-yearanniversary-aceh-trc/

IHL Database of ICRC About Customary IHL Rule 7, https://ihldatabases.icrc.org $>$ ihl

Stanford Encyclopedia of Philosophy. "Coloniaslism". Last modified August 29, 2017, https:// plato.stanford.edu/entries/colonialism/

United Nations Human Rights, "Basic Principles and Guidelines on the Right to a Remedy and Reparation for Victims of Grave Violations of International Human Rights Law and Serious Violations of International Humanitarian Law". https://www.ohchr.org/EN/ProfessionalInterest/Pages/RemedyAndR eparation.aspx

United Nations Human Rights, "Women's human rights and gender-related concerns in situations of conflict and instability". https://www.ohchr.org/EN/Issues/Women/WRGS/Pages/PeaceAndS ecurity.aspx 